\title{
ZEYTİNYAĞINDA MİNIMAL RAFİNASYON UYGULAMASININ İŞLEM PERFORMANSI VE KALİTE KRİTERLERİ AÇISINDAN DEĞERLENDİRİLMESİ
}

\author{
Merve Yazılıkaya Parasız, Onur Özdikicierler*, Fahri Yemişçioğlu \\ Ege Üniversitesi, Mühendislik Fakültesi, Gıda Mühendisliği Bölümü, İzmir, Türkiye
}

Geliş / Received: 23.10.2020; Kabul / Accepted: 20.01.2021; Online bask1 / Published online: 12.02.2021

Yazılıkaya-Parasız, M., Özdikicierler, O., Yemişçioğlu, F. (2021). Zeytinyağında minimal rafinasyon uygulamasının işlem performansı ve kalite kriterleri açısından değerlendirilmesi. GIDA (2021) 46(2) 311323 doi: 10.15237/gida. GD20123.

Yazılıaya-Parasız, M., Özdikicierler, O., Yemisçioğlu, F. (2021). Evaluation of minimal refining in olive oil in terms of processing performance and quality criteriai. GIDA (2021) 46(2) 311-323 doi: 10.15237/gida. GD20123.

\section{ÖZ}

$\mathrm{Bu}$ çalışmada rafinajlık zeytinyağı, sodyum hidroksit $(\mathrm{NaOH})$, magnezyum oksit $(\mathrm{MgO})$ ve kalsiyum hidroksit $\left(\mathrm{Ca}(\mathrm{OH})_{2}\right)$ olacak şekilde farkl kuvvetteki alkaliler ile asitlik giderme işlemine, natürel ve asitle aktifleştirilmiş değişken oranlardaki (\%0.1-\%0.5-\%0.9) ağartma topraklanı ile renk açma işlemine tabi tutulmuştur. $\mathrm{NaOH}$ ve $\mathrm{MgO}$ ile SYA miktarının etkin biçimde azaldığı ve rafinasyon kaybının $\mathrm{Ca}(\mathrm{OH})_{2}$ 'ye göre düşük olduğu tespit edilmiştir. Başlangıç TOTOX değeri 152.02 olan rafinajlık yağlarda bu değerin $\mathrm{NaOH}$ ve $\mathrm{MgO}$ ile gerçekleștirilen asitlik giderme işlemleri sonrasında sırasıyla 47.82 ve 56.9 'a düştügü ancak $\mathrm{Ca}(\mathrm{OH})_{2}$ ile 123.53 düzeyinde kaldığ1 görülmektedir. Asitliği giderilen örnekler arasında en yüksek fenolik bileşen içeriği $175.3 \mathrm{mg} / \mathrm{kg}$ ile $\mathrm{NaOH}$ örneğinde tespit edilmiştir. Natürel ağartma topraklarnnın kullanılmasının biyoaktif bileşenler açısından önemli bir koruma sağlamadığı ancak artan oranlarda kullanıldığında işlem etkinliği açısından asitle aktifleştirilmiş topraklara göre daha etkin sonuçlar verdiği tespit edilmiştir.

Anahtar kelimeler: minimal rafinasyon, zeytinyağı, asitlik giderme, renk açma, biyoaktif bileşen, tokoferol, fenolik bileşenler

\section{EVALUATION OF MINIMAL REFINING IN OLIVE OIL IN TERMS OF PROCESSING PERFORMANCE AND QUALITY CRITERIA}

\begin{abstract}
In this study, lampante olive oil was subjected to acidification treatment with alkalis with different strengths namely, sodium hydroxide $(\mathrm{NaOH})$, magnesium oxide $(\mathrm{MgO})$ and calcium hydroxide $\left(\mathrm{Ca}(\mathrm{OH})_{2}\right)$ and bleached with natural and acid-activated bleaching earths at variable ratios $(0.1 \%$ $0.5 \%-0.9 \%$ ). A decrease in the amount of FFA effectively achieved with $\mathrm{NaOH}$ and $\mathrm{MgO}$ and the refining loss is lower than $\mathrm{Ca}(\mathrm{OH})_{2}$. Initial TOTOX value of 152.02 , decreased to 47.82 and 56.9, respectively, after the de-acidification processes performed with $\mathrm{NaOH}$ and $\mathrm{MgO}$, but remained at the level of $\mathrm{Ca}(\mathrm{OH})_{2}$ and 123.53 . Among the neutralized samples, the highest phenolic component content was found in the $\mathrm{NaOH}$ sample with $175.3 \mathrm{mg} / \mathrm{kg}$. The use of natural bleaching soils in
\end{abstract}

${ }^{*}$ Yazışmalardan sorumlu yazar / Corresponding author

17: onur.ozdikicierler@ege.edu.tr, (1): (+90) 2323113001

且: (+90) 2323114831

Merve Yazılıkaya Parasız; ORCID no: 0000-0003-2051-9750

Onur Özdikicierler; ORCID no: 0000-0002-8959-4794

Fahri Yemiş̧̧ioğlu; ORCID no: 0000-0003-0860-5779 
bleaching processes does not provide significant protection in terms of bioactive components, but when used at increasing rates, it gives more effective results than acid activated soils in terms of processing efficiency.

Keywords: minimal refining, olive oil, neutralization, bleaching, bioactive components, tocopherol, phenolic compounds

\section{GİRIŞ̧}

Türk Gıda Kodeksi (TGK) Zeytinyağı ve Pirina Yağı Tebliğinde Natürel zeytinyağı, zeytin ağac1 meyvesinden doğal niteliklerinde değişikliğe neden olmayacak bir 1 sil ortamda, sadece yikama, dekantasyon, santrifüj ve filtrasyon işlemleri gibi mekanik veya fiziksel işlemler uygulanarak elde edilen; kendi kategorisindeki ürünlerin fiziksel, kimyasal ve duyusal özelliklerini taşıyan yağlar olarak tanımlanmaktadır (Gida Tarım ve Hayvancillk Bakanlığı, 2017). Natürel zeytinyağının alt kalite sınıflan; natürel sızma zeytinyağı, natürel birinci zeytinyağı ve ham zeytinyağ1/rafinajlık zeytinyağıdır. Ham olarak tüketilebilen natürel sızma ve natürel birinci kalite sınıfindaki natürel zeytinyağlarının tokoferol ve fenolik maddeler gibi biyoaktif bileşenleri önemli düzeyde içerdiği, bu nedenle özellikle să̆lıklı beslenme düzeninde önemli bir yeri olduğu bilinmektedir (Boskou, 2009; Preedy ve Watson, 2010; Sönmez, Özdikicierler ve Gümüşkesen, 2018). Natürel zeytinyağı sinıfindaki ham/rafinajlı zeytinyağları ise rafinasyon işlemi sonrasinda tüketime sunulurlar (Cmolik ve Pokorny, 2000). Rafinasyon, hidroliz ve oksidasyon gibi bozulma reaksiyonu ürünleri başta olmak üzere yağlardan istenmeyen tüm bileşenlerin uzaklaşturıldığ veya kabul edilebilir düzeye indirgendiği işlemler akışıdır. Rafinajlık zeytinyağlarına uygulanan rafinasyon işlemi genel olarak topraklama ve buhar distilasyonu aşamalarını içermekte ve işlemler sırasında uygulanan yüksek sıcaklık ve vakum koşulları zeytinyağlarında bulunan doğal biyoaktif bileşenlerin yağdan uzaklaşmasına yol açmaktadır. Bunun yanı sıra rafinasyon işlemleri sırasında yağ asitlerinin konjugasyonu gerçekleşebilmektedir (Ghazani ve Marangoni, 2013; Lucci, Bertoz, Pacetti, Moret ve Conte, 2020; Pan ve diğerleri, 2019; Verhé, Verleyen, Van Hoed ve De Greyt, 2008).

Son yıllarda bilimsel çalışmalarda yer bulan "Sağlık için Minimal Rafinasyon" kavramı, bitkisel yağların daha zayıf alkaliler ile asitliğinin giderilmesi, farklı ağartma toprakları veya teknikler ile renk açma işlemin gerçekleştirilmesi ve böylece yağda doğal olarak bulunan biyoaktif bileşenler mümkün olduğunca korunurken etkin bir rafinasyonun da sağlandığı yenilikçi teknikleri ifade etmektedir (Ghazani, 2012; Ghazani, García-Llatas ve Marangoni, 2013). Bitkisel yăg rafinasyonunda kimyasal asitlik giderme işlemi geleneksel olarak sodyum hidroksit $(\mathrm{NaOH})$ veya potasyum hidroksit $(\mathrm{KOH})$ ile gerçekleştirilebilmektedir. Kuvvetli alkaliler olan bu kimyasal maddelerin alternatifleri olarak orta kuvvetli bir alkali olan magnezyum oksit $(\mathrm{MgO})$ ve kalsiyum hidroksit $\left(\mathrm{Ca}(\mathrm{OH})_{2}\right)$, orta ve zaylf kuvvette alkaliler olarak minimal rafinasyon asitlik giderme aşaması için önerilmiştir (De ve Patel, 2011; Ghazani ve diğerleri, 2013).

Bu çalışmanın amacı, farklı kuvvetteki alkalilerin, değişken oranlarda kullanılan farklı ağartma topraklarının, asitlik giderme ve renk açma işlemlerinin performanslarına ve bu işlemler sırasında gerçekleşen biyoaktif bileşen kayıplarına etkilerinin incelenmesidir. $\mathrm{Bu}$ amaçla çalışmamızda rafinajlık zeytinyağı, $\mathrm{NaOH}, \mathrm{MgO}$ ve $\mathrm{Ca}(\mathrm{OH})_{2}$ kullanılarak rafinajlık zeytinyağlarına asitlik giderme işlemleri gerçekleştirilmiştir. Asitliği giderilen zeytinyağları çalışmanın ikinci aşamasında asitle aktive ve natürel olmak üzere iki farklı ağartma toprağ1 ile $\% 0.1, \% 0.5$ ve $\% 0.9$ olmak üzere üç farklı miktarda renk açma işlemine tabi tutulmuşlardır. İşlem sonrasında farklı alkalilerin işlem performansı üzerine etkisi SYA ve rafinasyon kaybı ile, renk açma işleminin performans1 ise toplam karotenoid ve klorofil miktarları üzerinden değerlendirilmiştir. İşlemlerin oksidasyon üzerine etkisi K232, K270, peroksit sayıs1, p-anisidin sayısı ve TOTOX değeri ile, biyoaktif bileşen üzerine etkisi ise toplam fenolik madde miktarı ve $\alpha$-tokoferol miktarı ile incelenmiştir. 


\section{MATERYAL VE YÖNTEM}

\section{Materyal}

Rafinajlık zeytinyağ1 örneği, İzmir'de faaliyet gösteren bir rafinasyon tesisinden temin edilmiştir. Rafinajlık zeytinyağ1 laboratuvara getirildikten sonra $500 \mathrm{~mL}$ lik amber şişelere paylaştırılmış ve kapak altı boşluklarındaki hava hafif bir azot akımı altında süpürülmüştür. Rafinajlık zeytinyağı örneği, denemelerin gerçekleştirileceği güne kadar $-20^{\circ} \mathrm{C}$ sıcaklıktaki depoda bekletilmiştir. Analizlerde kullanılan tüm kimyasal maddeler uygun saflık derecelerinde temin edilmişlerdir. Renk açma denemeleri için Balıkesir'de faaliyet gösteren bir ağartma toprağ1 üreticisinden temin edilen bentonit bazlı asitle aktive edilmiş ve natürel olmak üzere iki çeşit ağartma toprağ 1 kullanılmıştır.

\section{Yöntem}

\section{Asitlik giderme islemi}

Gerçekleştirilecek alkali nötralizasyon işlemlerinde kullanılacak $\mathrm{NaOH}, \mathrm{MgO}$ ve $\mathrm{Ca}(\mathrm{OH})_{2}$ için uygun miktar; rafinajlik zeytinyağının serbest yağ asidi içeriği baz alınarak stokiyometrik olarak hesaplanmıştır. Denemelerde hesaplanan alkali miktarı kadar kullanılmış, fazla alkali ilavesi (excess) uygulanmamıstır. Stokiyometrik olarak hesaplanan alkali miktarları; $\mathrm{NaOH} 0.52 \mathrm{~g}, \mathrm{MgO}$ $0.26 \mathrm{~g}, \mathrm{Ca}(\mathrm{OH})_{2} 0.48 \mathrm{~g}$ olup, bu miktarlar asitlik giderme denemelerinde kullanılmıştır.

Rafinajlık zeytinyağ1 örneklerinin asitliğinin giderilmesinde Ghazani vd. (2013) tarafindan açıklanmış olan "kanola yağında minimal rafinasyon prensibiyle alkali nötralizasyon işlemi”" modifiye edilerek uygulanmıştır. Asitlik giderme işlemi için $100 \mathrm{~g}$ yağ $60^{\circ} \mathrm{C}$ sicaklığa 1 sitılmıştır. Alkaliler ile hazırlanan sulu çözeltiler (saf su oranı yağın \%2.5’i olacak şekilde) yağa eklenerek yağ $60^{\circ} \mathrm{C}$ sicaklıkta 600 devir/dk hizda 20 dakika karışturma ile sabunlaşma reaksiyonunun tamamlanması sağlanmıştır. Reaksiyon sonrasında $5200 \mathrm{~g}$ (yerçekimsel güç) kuvvetinde $10 \mathrm{dk}$ santrifüj sonucu oluşan sabun fazı çökeltilmiştir. Sabun fazından ayrılan yağ örneğinde kalıntı sabunun uzaklaştırılması için yağ $80^{\circ} \mathrm{C}$ sıcaklığa 1sıtılarak yağın içerisine \%1 trysil (sentetik silika) ile \%1 Magnesol R60 (magnezyum silikat) eklenerek 600 devir/dakika hızda tekrar 20 dakika karıştrılmıstır. Karıştırma sonrasında eklenen adsorbantlar; 5200g kuvvetinde 10 dakika santrifüj uygulaması ve filtrasyon ile yağdan uzaklaştırılmıştır (Ghazani ve diğerleri, 2013).

\section{Renk acma işlemi}

Renk açma işlemi için Ghazani vd. (2013) ve Sabah ve Çelik (2005) tarafından açıklanmış olan laboratuvar ortamında renk açma işlemleri birlikte modifiye edilerek uygulanmıştır. Asitliği giderilmiş olan zeytinyağı bir cam reaktöre alınarak $30 \mathrm{~mm}$ $\mathrm{Hg}$ (40mbar) basınç altında karıştırma eşliğinde $55^{\circ} \mathrm{C}$ sicaklığa kadar 1situlip farklı oranlarda (\%0.1 - \%0.5 - \%0.9) ağartma toprağ (asitle aktive edilmiş veya natürel) eklenmiştir. Ağartma toprağının eklenmesinden sonra, $90^{\circ} \mathrm{C}$ sicaklıkta, 20 dakika süreyle karıştırma eşliğinde renk açma işlemi gerçekleştirilmiştir. İşlemler sonrasında rengi açılmış olan zeytinyağları filtre kağıdından süzülerek elde edilmişlerdir (Ghazani ve diğerleri, 2013; Sabah ve Çelik, 2005).

\section{Analizyöntemleri}

Serbest yağ asitliği (SYA), IUPAC Metot no:2.201 temel alınarak etanollü potasyum hidroksit çözeltisi titrasyonu ile tayin edilmiş ve sonuçlar \% oleik asit cinsinden verilmiştir. Asitlik giderme işleminde gerçekleşen rafinasyon kaybını tespit etmek için aşağıdaki eşitlik kullanılmıştır. Bu eşitliğe göre rafinasyon kaybının sıfıra yakın olması rafinasyon kaybının düşük olduğunu göstermektedir.

Rafinasyon kaybı $=1-m_{\text {nötr yă̆ }} /\left(m_{\text {ham yă̆ }}-m_{S Y A}\right)$

$\mathrm{m}_{\text {ham yă̆ }}=$ Alkali nötralizasyon öncesinde yağın toplam ağırlığ $(\mathrm{g})$

$\mathrm{m}_{\text {SYA }}=$ Ham yağın içerdiği toplam serbest yağ asitlerinin miktan $(\mathrm{g})$

$\mathrm{m}_{\text {nötr yă̆ }}=$ Asitliği giderilmiş olan yağın miktanı (g)

Peroksit değeri (PV) IUPAC Metot no: 2.501 kullanılarak sodyum tiyosülfat titrasyonu ile gerçekleştirilmiş ve sonuçlar meq $\mathrm{O}_{2} / \mathrm{kg}$ yağ cinsinden sunulmuştur. $\mathrm{p}$-anisidin değerinin ( $\mathrm{p}$ $\mathrm{anV}$ ) belirlenmesi için IUPAC Metot no: 2.504'da belirtilen spektrofotometrik yöntem izlenmiş ve sonuçlar $\mathrm{mmol} / \mathrm{kg}$ yağ cinsinden verilmiştir. Toplam oksidasyon değeri (TOTOX), 
Oksidasyonun birincil ve ikincil ürünlerinin toplamı üzerinden genel bir oksidasyon süreci değerlendirmesi yapmayı mümkün kilan bir değerdir ve TOTOX $=p-a n V+2 x$ PV formülü ile hesaplanır. UV 1şığında özgül absorbans (K232 ve K270) analizi için Türk G1da Kodeksi Zeytinyağı ve Pirina Yağı Analiz Metotlar1 Tebliği (Tebliğ No: 2014/53) kullanılmıştır. Toplam Fenolik Madde Miktarının ( $\mathrm{mg} / \mathrm{kg}$ ) belirlenmesi için Uluslararası Zeytinyağı Konseyi Metot No: COI/T.20/Doc No 29 kullanılmıştır ve sonuçlar gallik asit eşdeğeri (GEA) olarak verilmiştir. Zeytinyağı örneklerinde $\alpha$-tokoferol miktarlarının tespiti, Uluslararas1 zeytin konseyinin COI/T.20/Doc No 29 numaralı metodu takip edilerek HPLC ile gerçekleștirilmiştir. Renk açma işlemi sonrasında ve öncesinde zeytinyağ 1 örneklerinin toplam karotenoid ve toplam klorofil miktarları IUPAC Metot no:5.301'da belirtilen spektrofotometrik yöntem ile tespit edilmiştir.
Tüm denemeler iki kez ve analizler en az üç kez tekrarlanarak sonuçların kesinliği varyasyon katsayılarının devamlı kontrolü ile sağlanmıştır. İstatistiksel olarak farkların tespitinde ANOVA ve Tukey post-hoc testi kullanılmışır. Tüm istatistiksel testler $\alpha=0.05$ önem düzeyinde gerçekleştirilmiş ve $P<0.05$ olan tüm farklilıklar "istatistiksel olarak önemli bir fark vardır" şeklinde yorumlanmıştır.

\section{SONUÇLAR VE TARTIŞMA}

Çalışma öncelikle farklı alkali tipleri $(\mathrm{NaOH}$, $\mathrm{MgO}$ ve $\left.\mathrm{Ca}(\mathrm{OH})_{2}\right)$ ile gerçekleştirilen asitik giderme işlemleri daha sonra farklı tip ağartma toprakları ile gerçekleştirilen renk açma işlemleri ile devam etmiştir. Öncelikle asitlik giderme işleminin performansı, işlemin temel amacı olan SYA miktarındaki azalma ve işlem sırasında gerçekleşen rafinasyon kaybı üzerinden değerlendirilmiştir (Shahidi, 2005).

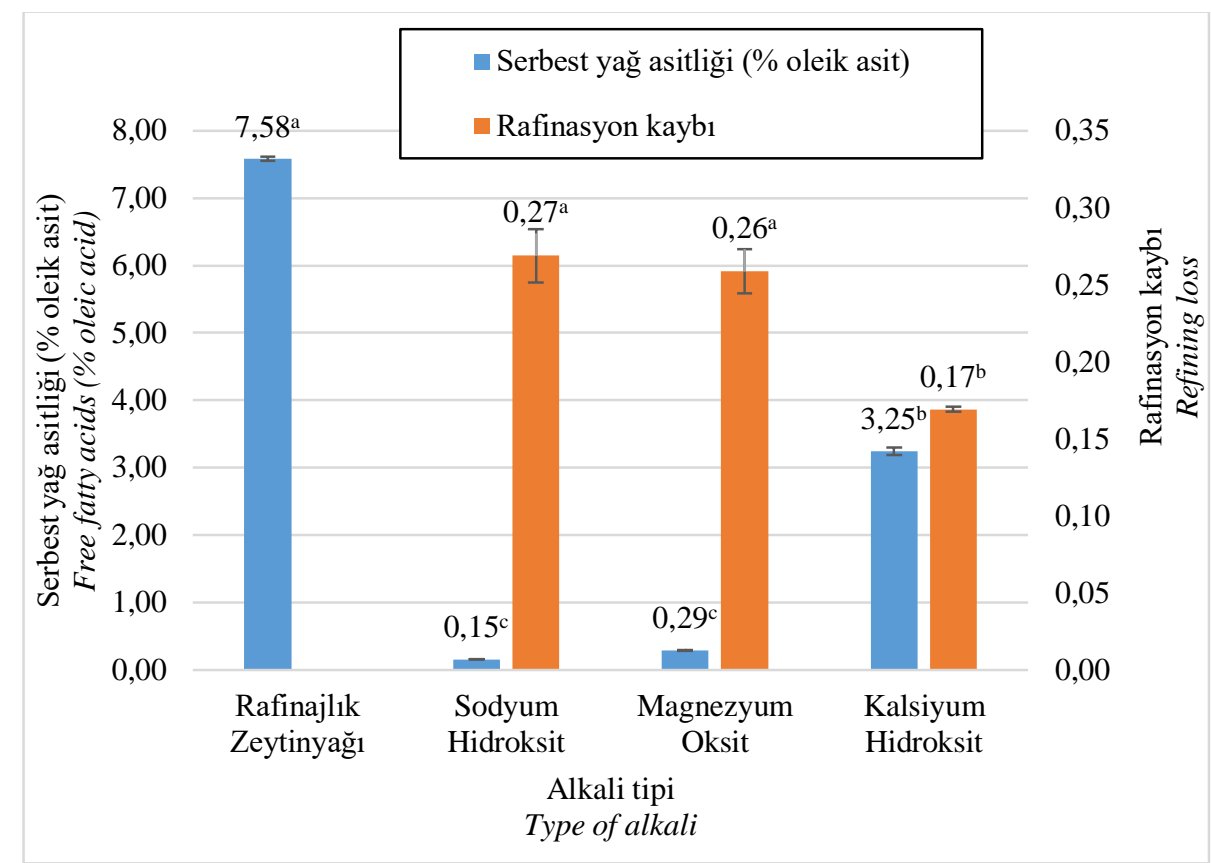

Aynı veri serisi boyunca değişen üst indis harfler Tukey testine göre grup farklılıkları ifade etmektedir. Superscript letters located on same sample group indicate statistical difference according to Tukey's test.

Şekil 1. Farklı alkaliler ile gerçekleştirilen asitlik giderme işlemi sonrasında yağların serbest yağ asitliği değerleri ve her alkali için rafinasyon kaybı değerleri

Figure 1. Free fatty acidity and refining loss for each alkali after the neutralization process performed with different alkalis 
Serbest yağ asitliğindeki azalma ve işlemler sırasında gerçekleşen rafinasyon kayıpları Şekil 1 'de verilmiştir. Rafinajlık zeytinyağının başlangıç serbest yağ asidi miktarının \%7.58 olduğu görülmektedir. $\mathrm{NaOH}$ ve $\mathrm{MgO}$ ile gerçekleştirilen asitlik giderme işlemleri sonrasina serbest yăg asitliğinin sırasıyla \%0.15 ve \%0.29'a düştüğü tespit edilmiş olup serbest yağ asitliğindeki azalma yönünden bu iki alkalinin istatistiksel bir fark göstermediği tespit edilmiştir. Ancak serbest yağ asitliği miktarında $\mathrm{Ca}(\mathrm{OH})_{2}$ kullanımı sonrasında etkin bir azalma yaşanmamış ve $\% 3.25$ düzeyinde kalmıştır. Gerçekleşen rafinasyon kayıpları karşılaştırıldığında $\mathrm{NaOH}$ ve $\mathrm{MgO}$ 'nun arasında önemli bir farklllık tespit edilmemiştir. Ancak $\mathrm{Ca}(\mathrm{OH})_{2}$ ile gerçekleştirilen asitlik giderme işlemi sonrasında rafinasyon kaybının daha düşük olduğu görülmüştür. Bu sonuçlar, asitlik giderme işleminin temel amacı olan serbest yağ asitliği miktarındaki azalma açısından geleneksel olarak kullanılan $\mathrm{NaOH}$ ile orta kuvvetteki alkali olan MgO'nun benzer etkiler gösterdiği ve rafinasyon kaybının da benzer düzeylerde gerçekleştiğini göstermiştir. $\mathrm{Ca}(\mathrm{OH})_{2}$ nin ise her ne kadar diğer alkalilere göre daha düşük bir rafinasyon kaybina sebep olsa da, serbest asitlik miktarını azaltmada istenilen etkiyi sağlayamadığı görülmüştür. Benzer bir çalışmada ise yapışkan maddelerinden arındırılmış kanola yağının $\% 0.55$ düzeyindeki SYA miktar1, $\mathrm{NaOH}, \mathrm{MgO}$ ve $\mathrm{Ca}(\mathrm{OH})_{2}$ ile gerçekleştirilen asitlik giderme işlemleri sonrasinda sirasiyla $\% 0.02, \% 0.08$ ve $\% 0.03$ düzeyine inmiş ve $\mathrm{Ca}(\mathrm{OH})_{2}$ 'in asitlik giderme işleminde $\mathrm{MgO}$ 'dan daha etkin sonuç verdiği ifade edilmiştir. Ancak ulaşılan SYA değerleri çok düşük düzeylerde olduğu için bu miktarlarda istatistiksel bir fark bulgulanmamıştır (Ghazani ve Marangoni, 2013).

Çizelge 1. Farklı alkaliler kullanılarak gerçekleştirilen asitlik giderme işlemleri sonucunda zeytinyağının oksidasyon parametrelerindeki değişimler

Table 1. Changes in the oxidation parameters of olive oil before and after of neutralization processes using different

\begin{tabular}{lccccc}
\multicolumn{5}{c}{ alkalis. } \\
& $\mathrm{K} 232$ & $\mathrm{~K} 270$ & $\begin{array}{c}\mathrm{PV} \\
(\mathrm{meq} \mathrm{O} / \mathrm{kg} \mathrm{yag})\end{array}$ & $\begin{array}{c}\mathrm{p}-\mathrm{anV} \\
(\mathrm{mmol} / \mathrm{kg} \text { yağ})\end{array}$ & TOTOX \\
\hline $\begin{array}{l}\text { Rafinajl1k } \\
\begin{array}{l}\text { Zeytinyağ1 } \\
\text { Lampante } \\
\text { olive oil }\end{array}\end{array}$ & $2.855 \pm 0.002^{\mathrm{a}}$ & $0.229 \pm 0.001^{\mathrm{b}}$ & $73.87 \pm 0.49^{\mathrm{a}}$ & $4.29 \pm 0.01^{\mathrm{a}}$ & $152.02 \pm 0.98^{\mathrm{a}}$ \\
$\mathrm{NaOH}$ & $2.468 \pm 0.001^{\mathrm{d}}$ & $0.200 \pm 0.001^{\mathrm{c}}$ & $22.64 \pm 1.03^{\mathrm{c}}$ & $2.55 \pm 0.01^{\mathrm{d}}$ & $47.82 \pm 2.05^{\mathrm{b}}$ \\
$\mathrm{MgO}$ & $2.692 \pm 0.002^{\mathrm{c}}$ & $0.352 \pm 0.001^{\mathrm{a}}$ & $27.03 \pm 0.59^{\mathrm{c}}$ & $2.84 \pm 0.01^{\mathrm{c}}$ & $56.9 \pm 1.18^{\mathrm{b}}$ \\
$\mathrm{CaOH}_{2}$ & $2.751 \pm 0.001^{\mathrm{b}}$ & $0.188 \pm 0.001^{\mathrm{d}}$ & $52.27 \pm 4.31^{\mathrm{b}}$ & $2.96 \pm 0.01^{\mathrm{b}}$ & $123.53 \pm 28.43^{\mathrm{a}}$ \\
\hline
\end{tabular}

Sütunlar boyunca değişen üst indis harfler, Tukey testine göre grup farkl11klarını ifade etmektedir.

Superscript letters, located along colums, represents statistical groupings according to Tukey's test.

Çizelge 1'de zeytinyağının asitlik giderme işlemi önce ve sonrasinda oksidasyon parametrelindeki değişim görülebilmektedir. Oksidasyonun birincil ürünleri ve iki çift bağ içeren konjuge yağ asidi (konjuge dien) miktarlarının bir göstergesi olan K232 değerinin rafinajlık zeytinyağında başlangiçta 2.855 olduğu tespit edilmiştir. K232 değerlerinde en etkin azalma $\mathrm{NaOH}$ ile gerçekleştirilen asitlik giderme işlemi sonrasında gözlemlenmiştir (2.468). Oksidasyonun ikincil ürünleri ile üçlü çift bağ içeren konjuge yağ asidi (konjuge trien) miktarlarının göstergesi olan K270 değerinin rafinasyon öncesinde 0.229 olarak ölçüldüğü, $\mathrm{NaOH}$ ve $\mathrm{CaOH}_{2}$ ile gerçekleştirilen asitlik giderme işlemi sonrasında sırasılyla 0.200 ve 0.188 düzeyine düştügü, ancak $\mathrm{MgO}$ ile gerçekleştirilen asitlik giderme işlemi sonrasında bu değerin 0.352 düzeyine yükseldiği tespit edilmiştir. K232 ve K270 değerlerindeki azalma için genel bir yorum yapıldığında $\mathrm{NaOH}$ 'n her iki değerde etkin azalma sağladığı görülmüsstür.

Asitlik giderme işlemi öncesinde rafinajllk zeytinyağının $\mathrm{PV}$ düzeyinin $73.87 \mathrm{meq} \mathrm{O}_{2} / \mathrm{kg}$ yağ olduğu görülmektedir. TGK'ye göre PV düzeyi 20'nin üzerinde olan natürel zeytinyağlanı lampant 
(rafinajlık) olarak tanımlanmaktadır. Genel olarak rafinasyonun asitlik giderme aşamasının birincil amacı oksidasyon ürünlerinin miktarında azalma sağlanması olmasa da, özellikle rafinasyonun ileri aşamalarındaki yükün azaltılması için tüm istenmeyen maddelerin miktarında gerçekleşecek azalmanın önemli olduğu düşünülmektedir. PV'nin istatistiksel olarak en etkin biçimde $\mathrm{NaOH}$ ve $\mathrm{MgO}$ ile gerçekleştirilen asitlik giderme işlemleri sonrasında azaldığ tespit edilmiştir (sirasiyla $22.64 \mathrm{meq} \mathrm{O}_{2} / \mathrm{kg}$ yağ ve $27.03 \mathrm{meq}$ $\mathrm{O}_{2} / \mathrm{kg}$ yağ). $\mathrm{Ca}(\mathrm{OH})_{2}$ ile gerçekleştirilen asitlik giderme işlemleri sırasında ise PV'nin $52.27 \mathrm{meq}$ $\mathrm{O}_{2} / \mathrm{kg}$ yağ seviyesine düştüğü görülmüştür. Peroksit sayıs1, kanola yağı ile gerçekleştirilen farklı bir çalışmada ise $\mathrm{NaOH}, \mathrm{MgO}$ ve $\mathrm{Ca}(\mathrm{OH})_{2}$ ile gerçekleştirilen asitlik giderme işlemlerinde yükselmiştir (Ghazani ve Marangoni, 2013). Oksidasyonun ikincil ürünleri olan aldehitlerin miktarının bir ifadesi olarak kullanılan p-anV, işlem öncesinde rafinajlık zeytinyağında 4.29 $\mathrm{mmol} / \mathrm{kg}$ yağ olarak tespit edilmiştir. Asitlik giderme işleminin, kullanılan alkali tipinden bağımsız olarak p-anV değerini azalttığ tespit edilmiştir. İstatistiksel olarak $\mathrm{p}$-anV değerinde en fazla düşüş $\mathrm{NaOH}$ ile gerçekleştirilen asitlik giderme işlemi sırasında gerçekleşmiştir (2.55 $\mathrm{mmol} / \mathrm{kg}$ yağ). Oksidasyonun genel bir ifadesi olan TOTOX değeri, PV ve p-anV değerleri ile hesaplanan bir göstergedir. Asitlik giderme işlemleri öncesinde rafinajlı zeytinyağı örneğinin TOTOX değerinin 152.02 olduğu, $\mathrm{NaOH}$ ve $\mathrm{MgO}$ alkalilerinin bu değerin önemli düzeyde azalmasını sağladığı $(\mathrm{NaOH}$ ve $\mathrm{MgO}$ için sırasıyla 47.82 ve 56.9 ), $\mathrm{CaOH}_{2}$ ile gerçekleştirilen asitlik giderme işlemi sırasında ise TOTOX değerinde önemli bir azalma gerçekleşmediği (123.53) görülmektedir. Çizelge 1'de verilen tüm oksidasyon göstergelerinin genel bir yorumu yapılmak istendiğinde ise çalışmamızın sonuçlarına göre $\mathrm{NaOH}$ ile gerçekleştirilen asitlik giderme isslemlerinde, oksidasyon ürünlerinin diğer alkalilere göre daha etkin biçimde azaldığ tespit edilmiştir.

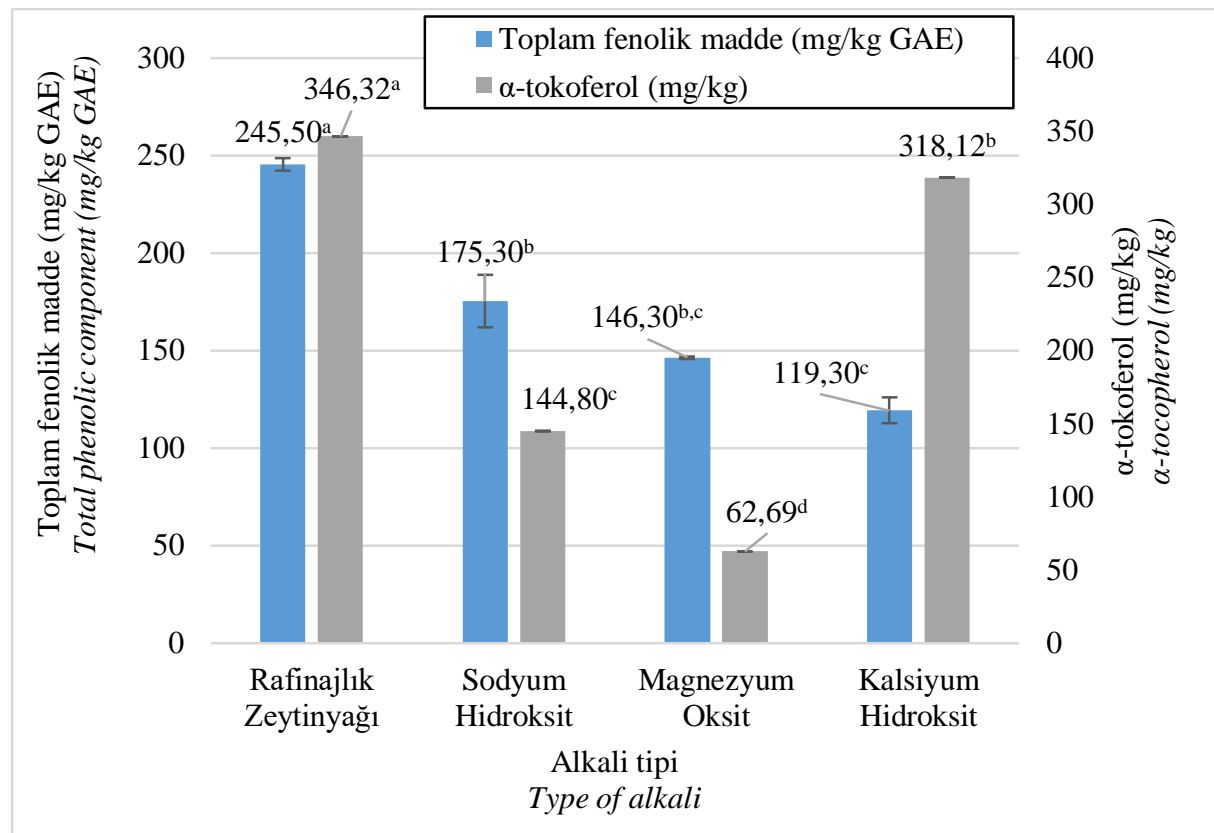

Şekil 2. Farklı alkaliler kullanılarak gerçekleştirilen asitlik giderme işlemleri sonucunda zeytinyağının biyoaktif bileşenlerindeki değişimler.

Figure 2. Changes in the bioactive components of olive oil as a result of neutralization reactions using different alkalis.

Toplam fenolik madde ve zeytinyağ 1 tokoferollerinden en baskın izomer $\alpha$-tokoferolün konsantrasyonlarnnda, asitlik giderme denemeleri sırasında kullanılan alkali tipine bağlı olarak gerçekleşen değişimler Şekil 2'de verilmiştir. Rafinajlık zeytinyağında asitlik giderme işlemleri 
öncesinde toplam fenolik madde ve $\alpha$-tokoferol sirasiyla $245.50 \mathrm{mg} / \mathrm{kg}$ GAE ve $346 \mathrm{mg} / \mathrm{kg}$ olarak bulunmuştur. Toplam fenolik madde miktarındaki en fazla azalma, $\mathrm{Ca}(\mathrm{OH})_{2}$ ile asitliği giderilmiş zeytinyağında (119.3 mg/kg GAE) tespit edilmiştir. Her ne kadar Tukey gruplar1 incelendiğinde $\mathrm{NaOH}$ ve $\mathrm{MgO}$ ile $\mathrm{MgO}$ ve $\mathrm{Ca}(\mathrm{OH})_{2}$ alkali ikilileri arasinda istatistiksel grup fark1 tespit edilmemiş olsa da, $\mathrm{NaOH}$ ile gerçekleştirilen asitlik giderme işlemi sonrasında tespit edilen toplam fenolik madde konsantrasyonu (175.3 mg/kg GAE), diğer alkalilere göre daha yüksektir. $\alpha$-tokoferol miktarları karşılaştırıldığında ise $\mathrm{Ca}(\mathrm{OH})_{2}$ ile gerçekleştirilen asitlik giderme işlemi sonrasında $\alpha$-tokoferol konsantrasyonundaki $(318.12 \mathrm{mg} / \mathrm{kg}$ ) azalmanın çok düşük olduğu, MgO'da ise $\alpha$ tokoferol miktarındaki azalmanın $(62.69 \mathrm{mg} / \mathrm{kg})$ en fazla gerçekleştiği tespit edilmiştir. Genel olarak, çalışmamızda kullanılan alkali tiplerinin asitlik giderme işlem performansları dikkate alınmadan sadece biyoaktif bileşenler üzerindeki etkileri karşılaştırlacak olursa, Toplam fenolik madde konsantrasyonunda en az düşüşe neden olan alkalinin $\mathrm{NaOH}, \quad \alpha$-tokoferol konsantrasyonunda en az düşüşe neden olan alkalinin ise $\mathrm{Ca}(\mathrm{OH})_{2}$ olduğu görülmektedir.

Çizelge 2. Farklı alkaliler ile asitliği giderilmiş zeytinyağı örneklerinde toprak tipi ve toprak miktarının zeytinyağının genel kalite kriterleri üzerine etkisi

Table 2. The effect of bleaching earth type and amount on the general quality criteria of olive oil neutralized with different alkalis.

\begin{tabular}{|c|c|c|c|c|c|c|}
\hline $\mathrm{NaOH}$ & $\begin{array}{c}\text { SYA } \\
(\% \text { oleik asit })\end{array}$ & K232 & $\mathrm{K} 270$ & $\begin{array}{c}\mathrm{PV} \\
\left(\text { meq } \mathrm{O}_{2} / \mathrm{kg} \text { yağ) }\right.\end{array}$ & $\underset{(\mathrm{mmol} / \mathrm{kg})}{\mathrm{p}-\mathrm{anV}}$ & TOTOX \\
\hline $\begin{array}{l}\text { Nötr Yağ } \\
\text { Neutralized oil }\end{array}$ & $0.09 \pm 0^{\mathrm{b}}$ & $2.469 \pm 0 c$ & $0.200 \pm 0 \mathrm{~g}$ & $22.64 \pm 0.73^{a}$ & $2.55 \pm 0 \mathrm{~g}$ & $47.82 \pm 1.45^{\mathrm{a}}$ \\
\hline \multicolumn{7}{|c|}{$\begin{array}{l}\text { Asit aktive ağartma toprağ1 } \\
\text { Acid acitivated bleaching earth }\end{array}$} \\
\hline$\% 0.1$ & $0.64 \pm 0.01^{a}$ & $2.620 \pm 0.001$ a.b & $0.305 \pm 0.01 \mathrm{~d}$ & $22.54 \pm 0.34 a$ & $8.06 \pm 0 \mathrm{~b}$ & $53.15 \pm 0.68^{a}$ \\
\hline$\% 0.5$ & $0.66 \pm 0.04^{a}$ & $2.136 \pm 0^{\mathrm{d}}$ & $0.389 \pm 0^{\mathrm{b}}$ & $19.30 \pm 1.46^{a}$ & $5.2 \pm 0 \mathrm{e}$ & $43.78 \pm 2.91^{\mathrm{a}}$ \\
\hline$\% 0.9$ & $0.68 \pm 0.01^{\mathrm{a}}$ & $2.549 \pm 0.002^{\mathrm{b}}$ & $0.503 \pm 0^{\mathrm{a}}$ & $19.52 \pm 0.71^{\mathrm{a}}$ & $8.57 \pm 0^{\mathrm{a}}$ & $47.61 \pm 1.41^{\mathrm{a}}$ \\
\hline \multicolumn{7}{|c|}{$\begin{array}{l}\text { Natürel ağartma toprağı } \\
\text { Natural bleaching earth }\end{array}$} \\
\hline$\% 0.1$ & $0.13 \pm 0.01 \mathrm{~b}$ & $2.648 \pm 0.001 \mathrm{a}$ & $0.230 \pm 0^{f}$ & $24.00 \pm 1.57 \mathrm{a}$ & $5.32 \pm 0 \mathrm{~d}$ & $53.3 \pm 3.13^{a}$ \\
\hline$\% 0.5$ & $0.15 \pm 0.02^{\mathrm{b}}$ & $2.646 \pm 0.025^{a}$ & $0.255 \pm 0^{\mathrm{e}}$ & $23.66 \pm 1.77 \mathrm{a}$ & $5.61 \pm 0^{c}$ & $52.92 \pm 3.54^{a}$ \\
\hline$\% 0.9$ & $0.16 \pm 0.01^{b}$ & $2.451 \pm 0.001^{\mathrm{c}}$ & $0.333 \pm 0^{c}$ & $23.01 \pm 4.05^{\mathrm{a}}$ & $4.16 \pm 0^{f}$ & $50.18 \pm 8.09^{a}$ \\
\hline $\mathrm{MgO}$ & SYA & K232 & K270 & $\begin{array}{c}\mathrm{PV} \\
\left(\text { meq } \mathrm{O}_{2} / \mathrm{kg} \text { yağ }\right)\end{array}$ & $\begin{array}{c}\mathrm{p}-\mathrm{anV} \\
(\mathrm{mmol} / \mathrm{kg})\end{array}$ & TOTOX \\
\hline $\begin{array}{l}\text { Nötr Yağ } \\
\text { Neutralized oil }\end{array}$ & $0.19 \pm 0.01^{b}$ & $2.692 \pm 0.001^{\mathrm{d}}$ & $0.352 \pm 0^{a . b}$ & $27.03 \pm 0.42^{\mathrm{d}}$ & $2.84 \pm 0 \mathrm{e}$ & $56.9 \pm 0.83^{d}$ \\
\hline \multicolumn{7}{|c|}{$\begin{array}{l}\text { Asit aktive ağartma toprağ1 } \\
\text { Acid acitivated bleaching earth }\end{array}$} \\
\hline$\% 0.1$ & $0.61 \pm 0.01^{\mathrm{a}}$ & $2.902 \pm 0.005^{a}$ & $0.237 \pm 0^{\mathrm{c.d}}$ & $44.84 \pm 1.86^{c}$ & $3.49 \pm 0^{\mathrm{d}}$ & $93.17 \pm 3.71^{\mathrm{c}}$ \\
\hline$\% 0.5$ & $0.64 \pm 0.03^{\mathrm{a}}$ & $2.705 \pm 0.002^{\mathrm{d}}$ & $0.290 \pm 0.03^{b . c}$ & $66.12 \pm 1.80^{a}$ & $7.37 \pm 0^{\mathrm{a}}$ & $139.6 \pm 3.6^{a}$ \\
\hline$\% 0.9$ & $0.66 \pm 0 \mathrm{a}$ & $2.559 \pm 0.001^{a}$ & $0.420 \pm 0 \mathrm{a}$ & $52.44 \pm 3.05^{\text {b.c }}$ & $5.88 \pm 0^{\mathrm{b}}$ & $110.75 \pm 6.1 \mathrm{~b} . \mathrm{c}$ \\
\hline \multicolumn{7}{|c|}{$\begin{array}{l}\text { Natürel ağartma toprağ1 } \\
\text { Natural bleacbing earth }\end{array}$} \\
\hline$\% 0.1$ & $0.77 \pm 0.01 \mathrm{a}$ & $2.860 \pm 0.003^{b}$ & $0.194 \pm 0 \mathrm{~d}$ & $50.32 \pm 2.26^{b . c}$ & $2.24 \pm 0^{\mathrm{f}}$ & $102.87 \pm 4.52^{b . c}$ \\
\hline$\% 0.5$ & $0.57 \pm 0.18 \mathrm{a} . \mathrm{b}$ & $2.736 \pm 0 c$ & $0.205 \pm 0 \mathrm{c.d}$ & $58.38 \pm 1.78^{a . b}$ & $3.49 \pm 0 \mathrm{~d}$ & $120.25 \pm 3.56^{a . b}$ \\
\hline$\% 0.9$ & $0.39 \pm 0^{a . b}$ & $2.748 \pm 0^{c}$ & $0.231 \pm 0^{c . d}$ & $55.08 \pm 0.05^{\text {b.c }}$ & $3.51 \pm 0^{c}$ & $113.65 \pm 0.11^{b . c}$ \\
\hline
\end{tabular}


M. Yazılıkaya Parasız, O. Özdikicierler, F. Yemişçioğlu

\begin{tabular}{|c|c|c|c|c|c|c|}
\hline $\mathrm{Ca}(\mathrm{OH})_{2}$ & SYA & K232 & K270 & $\begin{array}{c}\mathrm{PV} \\
\left(\mathrm{meqO}_{2} / \text { kgyağ }\right)\end{array}$ & $\begin{array}{c}\mathrm{p}-\mathrm{anV} \\
(\mathrm{mmol} / \mathrm{kg})\end{array}$ & TOTOX \\
\hline $\begin{array}{l}\text { Nötr Yağ } \\
\text { Neutralized oil }\end{array}$ & $5.69 \pm 0.06^{\mathrm{a}}$ & $2.750 \pm 0.001 \mathrm{e}$ & $0.188 \pm 0 \mathrm{~g}$ & $52.27 \pm 3.05^{a}$ & $2.96 \pm 0 \mathrm{e}$ & $123.53 \pm 16.42^{a}$ \\
\hline \multicolumn{7}{|c|}{$\begin{array}{l}\text { Asit aktive ağartma toprağı } \\
\text { Acid acitivated bleaching earth }\end{array}$} \\
\hline$\% 0.1$ & $0.09 \pm 0 \mathrm{c}$ & $2.830 \pm 0.005^{\mathrm{c}}$ & $0.327 \pm 0^{\mathrm{d}}$ & $54.49 \pm 2.87 \mathrm{a}$ & $6.92 \pm 0^{c}$ & $115.9 \pm 5.74 \mathrm{a}$ \\
\hline$\% 0.5$ & $0.1 \pm 0.01 \mathrm{c}$ & $2.984 \pm 0^{a}$ & $0.424 \pm 0^{\mathrm{b}}$ & $56.17 \pm 4.19 \mathrm{a}$ & $7.07 \pm 0 \mathrm{a}$ & $119.4 \pm 8.38 \mathrm{a}$ \\
\hline$\% 0.9$ & $0.11 \pm 0 c$ & $2.904 \pm 0.005^{b}$ & $0.470 \pm 0^{a}$ & $44.06 \pm 1.51^{a}$ & $6.71 \pm 0.01 \mathrm{~d}$ & $94.82 \pm 3.01^{a}$ \\
\hline \multicolumn{7}{|c|}{$\begin{array}{l}\text { Natürel ağartma toprağ1 } \\
\text { Natural bleaching earth }\end{array}$} \\
\hline$\% 0.1$ & $0.5 \pm 0.01^{\mathrm{b}}$ & $2.833 \pm 0.005^{c}$ & $0.279 \pm 0^{\mathrm{f}}$ & $22.64 \pm 3.01^{b}$ & $1.63 \pm 0 \mathrm{~g}$ & $46.91 \pm 6.02^{\mathrm{b}}$ \\
\hline$\% 0.5$ & $0.49 \pm 0.01 \mathrm{~b}$ & $2.799 \pm 0.002^{\mathrm{d}}$ & $0.316 \pm 0 \mathrm{e}$ & $50.11 \pm 0.75^{a}$ & $2.55 \pm 0^{\mathrm{f}}$ & $102.75 \pm 1.51^{\mathrm{a}}$ \\
\hline$\% 0.9$ & $0.5 \pm 0^{\mathrm{b}}$ & $2.767 \pm 0.001 \mathrm{e}$ & $0.359 \pm 0 \mathrm{c}$ & $27.91 \pm 1.58 \mathrm{~b}$ & $7.02 \pm 0^{\mathrm{b}}$ & $62.83 \pm 3.17 \mathrm{~b}$ \\
\hline
\end{tabular}

Her farklı alkali ile asitlik giderilmiş zeytinyağı örneği için ayr1 ayrı olacak şekilde sütunlar boyunca değişen üst indis harfler, Tukey testine göre iki farklı ağartma toprağı ve üç farklı toprak miktarı için istatistiksel grup farklılıklarını ifade etmektedir.

The superscript letters varying along the columns for each different alkali express the statistical group differences for two different bleaching soils and three different soil amounts according to the Tukey's test.

Çizelge 2'de $\mathrm{NaOH}, \mathrm{MgO}$ ve $\mathrm{Ca}(\mathrm{OH})_{2}$ ile asitlik giderme işlemi uygulanan rafinajlık zeytinyağlarının ayrı ayrı olacak şekilde asitle aktive ve natürel ağartma topraklarının farklı oranları $(\% 0.1-\% 0.5-\% 0.9)$ ile gerçekleştirilen renk açma işlemi sonrasında genel kalite kriterlerinin değişimi sunulmuştur. Öncelikle SYA'da en etkin azalmanın sağlandığı $\mathrm{NaOH}$ ile asitliği giderilmiş yağlarda natürel ağartma toprağ1 ile yapılan renk açma işlemlerinde \%0.09 olan SYA'nin toprak miktarının etkisi olmaksızın $\% 0.13-\% 0.16$ aralığında kaldığ ağartma toprağı kullanıldığında bu değerin \%0.64$\% 0.68$ aralı̆̆ına yükseldiği görülmektedir. $\mathrm{Bu}$ durum, renk açma aşamasında asitle aktive ağartma toprağı kullanılmasinın SYA yükselmesine neden olabileceği ile açıklanabilmektedir. $\mathrm{MgO}$ ve $\mathrm{Ca}(\mathrm{OH})_{2}$ ile asitliği giderilen örneklerde ise SYA değerinin etkin biçimde azaltılamaması nedeniyle asitle aktive ve natürel ağartma toprakları hakkında benzer bir etkinin tespiti net olarak yapılamamaktadır.

$\mathrm{NaOH}$ ve $\mathrm{CaOH}_{2}$ ile asitliği giderilmiş yağlarda ağartma toprağ1 tipi ve miktarından bağımsız olarak K232 ve K270 değerlerinde belirli bir yükselme tespit edilmiştir. $\mathrm{MgO}$ ile asitliği giderilmiş zeytinyağında ise K232 değerinde benzer bir artış gözlemlenirken K270 değerinde azalma söz konusudur. Her ne kadar K232 ve K270 değerlerindeki bu değişimlerin çoğu istatistiksel olarak önemli olarak tespit edilmiş olsa da değişim miktarlarının düşük olduğu söylenebilmektedir. Genel olarak $\mathrm{NaOH}$ dışındaki alkaliler ile gerçekleştirilen renk açma işlemlerinde, toprak miktarından bağımsız olarak PV değerlerinde istatistiksel bir artış söz konusudur. $\mathrm{NaOH}$ ile asitliği giderilen zeytinyağlarının renk açma denemelerinde PV değerinde istatistiksel bir artış tespit edilmemesi, asitlik giderme aşamasında $\mathrm{NaOH}$ kullanımının, renk açma işleminde bu açıdan avantaj sağladığ söylenebilmektedir. Oksidasyonun ikincil ürünlerinin göstergesi olan $\mathrm{p}$-anV değeri, tüm alkali tipleri için incelendiğinde renk açma işlemleri sonrasında belirli oranda yükselmiştir. Ancak, bu yükselişler natürel ağartma topraklarının kullanılması durumunda daha düşük düzeydedir. Örneğin $\mathrm{NaOH}$ ile asitliği giderilen zeytinyağlanında $2.55 \mathrm{mmol} / \mathrm{kg}$ yağ olan $\mathrm{p}$-anV düzeyi, asitle aktive ağartma toprağı kullanıldığ zaman toprak miktarına bağlı olarak $5.2 \mathrm{mmol} / \mathrm{kg}$ yağ $-8.57 \mathrm{mmol} / \mathrm{kg}$ yağ aralığına yükselirken, natürel ağartma toprağında bu değer 4.16 $\mathrm{mmol} / \mathrm{kg}$ yağ $-5.61 \mathrm{mmol} / \mathrm{kg}$ yağ aralığında değişmektedir. 


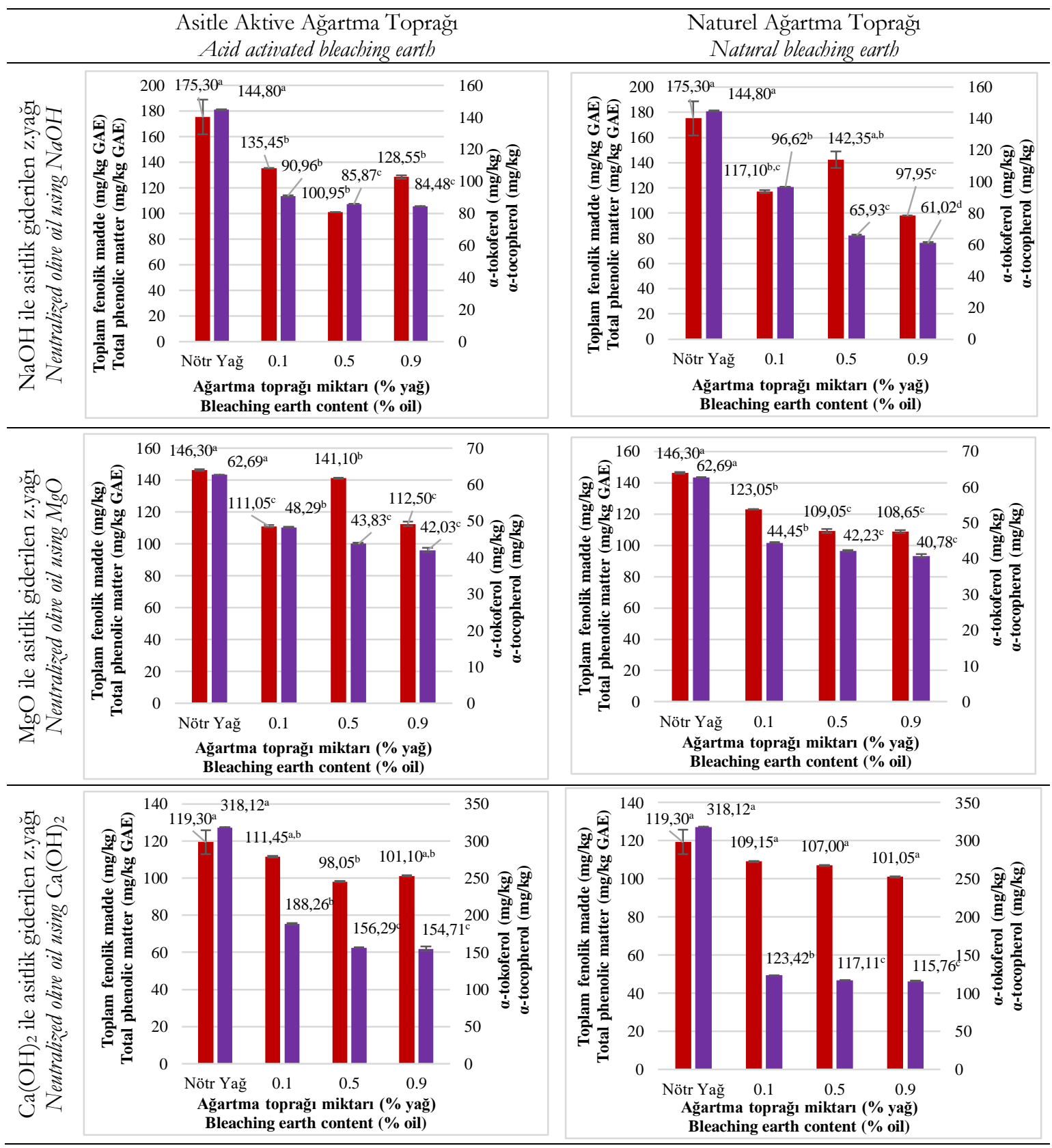

Her grafik için ayrı ayrı olacak şekilde kendi veri serisi içinde değişen üst indis harfler (toplam fenolik madde ve $\alpha$-tokoferol için ayrı ayrı değerlendirilmelidir), Tukey testine göre grup farklılıklarını ifade etmektedir. Kırmızı barlar ile ifade edilen toplam fenolik madde solda bulunan birincil eksende, eflatun renkli barlar ile ifade edilen $\alpha$-tokoferol ise sağda bulunan ikincil eksende gösterilmektedir.

Superscript letters (which should be evaluated separately for total phenolic content and a-tocopherol) represent group differences according to Tukey's test. The total phenolic content represented by red bars and is shown on the primary axis on the left, and a-tocopherol expressed by the magenta bars on the secondary axis on the right.

Şekil 3. $\mathrm{NaOH}, \mathrm{MgO}$ ve $\mathrm{Ca}(\mathrm{OH})_{2}$ ile asitlik giderme uygulanmış zeytinyağı örneklerinin değişsen miktarlarda farklı ağartma topraklarıyla renk açma işlemine tabi tutulması sonucunda yağların biyoaktif bileşen miktarındaki (toplam fenolik madde ve $\alpha$-tokoferol konsantrasyonları) değişimler.

Figure 3. Changes in the amount of bioactive components (total phenolic and a-tocopherol concentrations) of olive oil samples, which were neutralized with $\mathrm{NaOH}, \mathrm{MgO}$ and $\mathrm{Ca}(\mathrm{OH})_{2}$, and bleaching with varying amounts of different bleaching earths. 
Farklı alkali tipleri ile asitliği giderilen zeytinyağlarında toprak tipi ve miktarının toplam fenolik madde ve $\alpha$-tokoferol konsantrasyonları üzerine etkisini gösteren Şekil 3'de verilmiş olan grafikler incelendiğinde, renk açma işlemi sonrasında biyoaktif bileşen miktarlarında bir düşüş yaşandığı görülmektedir. $\mathrm{NaOH}$ ile asitliği giderilen zeytinyağlarında toplam fenolik madde konsantrasyonlarının toprak miktarı artış1 ile düzenli bir değişiklik göstermediği ancak toprak miktarı arttıkça $\alpha$-tokoferol miktarlarının azaldığı görülmektedir. $\mathrm{NaOH}$ ile asitliği giderilen zeytinyağlarında $\% 0.9$ oranda asitle aktive ağartma toprağı kullanılarak gerçekleştirilen renk açma işlemleri sonrasında $\alpha$-tokoferol düzeyi 84.48 $\mathrm{mg} / \mathrm{kg}$ 'e inerken aynı oranda kullanilan natürel ağartma toprağında ise bu değer $61.02 \mathrm{mg} / \mathrm{kg}$ 'a kadar düşmüştür. Benzer etkiler, $\mathrm{MgO}$ ve $\mathrm{Ca}(\mathrm{OH})_{2}$ ile elde edilen nötr yağlardaki $\alpha$ tokoferol değerlerinde de gözlemlenmektedir. Özellikle $\mathrm{Ca}(\mathrm{OH})_{2}$ ile asitliği giderilen zeytinyağlarının $\% 0.1$ oranda natürel ağartma toprağ 1 ile renk açma işlemine tabi tutulması sonunda $\alpha$-tokoferol değerlerinin $318.12 \mathrm{mg} / \mathrm{kg}$ seviyesinden $\quad 123.42 \mathrm{mg} / \mathrm{kg}^{\prime} \mathrm{a}$ indiği görülmektedir. Yapılan denemeler genel olarak değerlendirildiğinde, artan ağartma toprağ 1 miktarları genel olarak biyoaktif bileşen kaybını arttırdığ1 görülmektedir. Biyoaktif bileşenler üzerinde benzer bir etki kanola yağının farklı alkaliler ile nötralizasyonu sonrasinda da gözlenmiştir. Özellikle $\alpha$-tokoferol miktarının asitlik giderme ve renk açma aşamalarında 135 $\mathrm{mg} / \mathrm{kg}$ düzeyinden önce $107.3 \mathrm{mg} / \mathrm{kg}$ seviyesine, oradan da renk açma sonrasında $92.3 \mathrm{mg} / \mathrm{kg}$ düzeyine inmesi, rafinasyon işleminin biyoaktif bileşenler üzerine etkisini net biçimde ortaya koymaktadır (Ghazani ve Marangoni, 2013).

Renk açma işleminin temel amacı olan karotenoid ve klorofil gibi yağlarda bulunan renk maddelerinin azaltılmasıdır. Farklı alkali tipleri ile asitliği giderilen zeytinyağlarında toprak tipi ve miktarının toplam karotenoid ve klorofil miktarları üzerine etkisini gösteren grafikler Şekil 4'de verilmiştir. $\mathrm{NaOH}$ ile asitlik giderme işlemi yapılan zeytinyağı örneklerinde asit aktive ağartma toprağının $\% 0.1$ oranında kullanılması durumunda bile karotenoid miktarı $2.88 \mathrm{mg} / \mathrm{kg}$ seviyesinden $1.57 \mathrm{mg} / \mathrm{kg}$ 'a azalmıştır. Natürel ağartma toprağında ise benzer karotenoid miktarlarına ulaşmak için $\% 0.5$ oranında ağartma toprağ1 kullanılması gerekmiştir. Ancak natürel ağartma toprağının artan miktarları kullanıldığında karotenoid ve klorofil seviyeleri kademeli biçimde daha fazla azalırken asitle aktive ağartma toprağ1 için aynı durum söz konusu değildir. $\mathrm{MgO}$ ile asitlik giderme uygulanan zeytinyağlarında başlangıç karotenoid $(11.33 \mathrm{mg} / \mathrm{kg})$ ve klorofil $(2.07 \mathrm{mg} / \mathrm{kg})$ düzeyleri diğer alkaliler ile asitlik giderme işlemi uygulanmış yağlara göre çok daha yüksektir. $\mathrm{Bu}$ nedenle, $\mathrm{MgO}$ örneklerinde renk açma işlemi sonrasında pigment maddelerindeki düşüşün fazla olduğu görülüyor olsa da her iki toprak tipi için de bu değerlerin $\mathrm{NaOH}$ örneklerinden daha yüksek seyrettiği görülebilmektedir. Renk açma işlemlerinin $\mathrm{Ca}(\mathrm{OH})_{2}$ ile asitliği giderilen zeytinyağlarındaki etkinlikleri incelendiğinde başlangıç karotenoid miktarlarının diğer alkalilere göre daha düşük olduğu $(1.9 \mathrm{mg} / \mathrm{kg})$ görülmektedir. Bu örneklerin renk açma denemelerinde asitle aktive toprak kullanıldığında toprak miktarındaki artışın klorofil miktar1 üzerine düzenli bir etkisi tespit edilemezken klorofil miktarlar1 $0.39 \mathrm{mg} / \mathrm{kg}$ başlangıç seviyesinden $\% 0.1$ ve $\% 0.5$ toprak miktarlarında $0.08 \mathrm{mg} / \mathrm{kg}$ seviyesine indiği görülmektedir. Buna rağmen, \%0.9 natürel ağartma toprağ 1 kullanıldığında bile $\mathrm{Ca}(\mathrm{OH})_{2}$ ile asitliği giderilen zeytinyağlarında karotenoid ve klorofil seviyesinin sirasiyla $1.59 \mathrm{mg} / \mathrm{kg}$ ve 0.12 $\mathrm{mg} / \mathrm{kg}$ seviyesine geldiği görülmektedir. $\mathrm{Bu}$ değerler aynı oranda asitle aktive ağartma toprağı kullanıldığında sırasıyla $3.34 \mathrm{mg} / \mathrm{kg}$ ve 0.13 $\mathrm{mg} / \mathrm{kg}$ olarak tespit edilmiştir. Diğer alkali tipleri ile kıyaslandığında $\mathrm{Ca}(\mathrm{OH})_{2}$ örneklerinde renk açma etkinliğinin daha düşük olduğu görülmektedir. $\mathrm{Ca}(\mathrm{OH})_{2}$ ile asitliği giderilen zeytinyağlanında başlangıç SYA, PV düzeylerinin diğer alkali tiplerine ait örneklere kıyasla daha yüksek olması, bu örnekler için eklenen ağartma topraklarında kirletici unsur olarak rol oynadığ1, bu nedenle pigment maddelerinin adsorbsiyonunda beklenen azalma miktarlarina ulaşılamadığ1 düşünülmektedir (Brien, Farr ve Wan, 2000). 


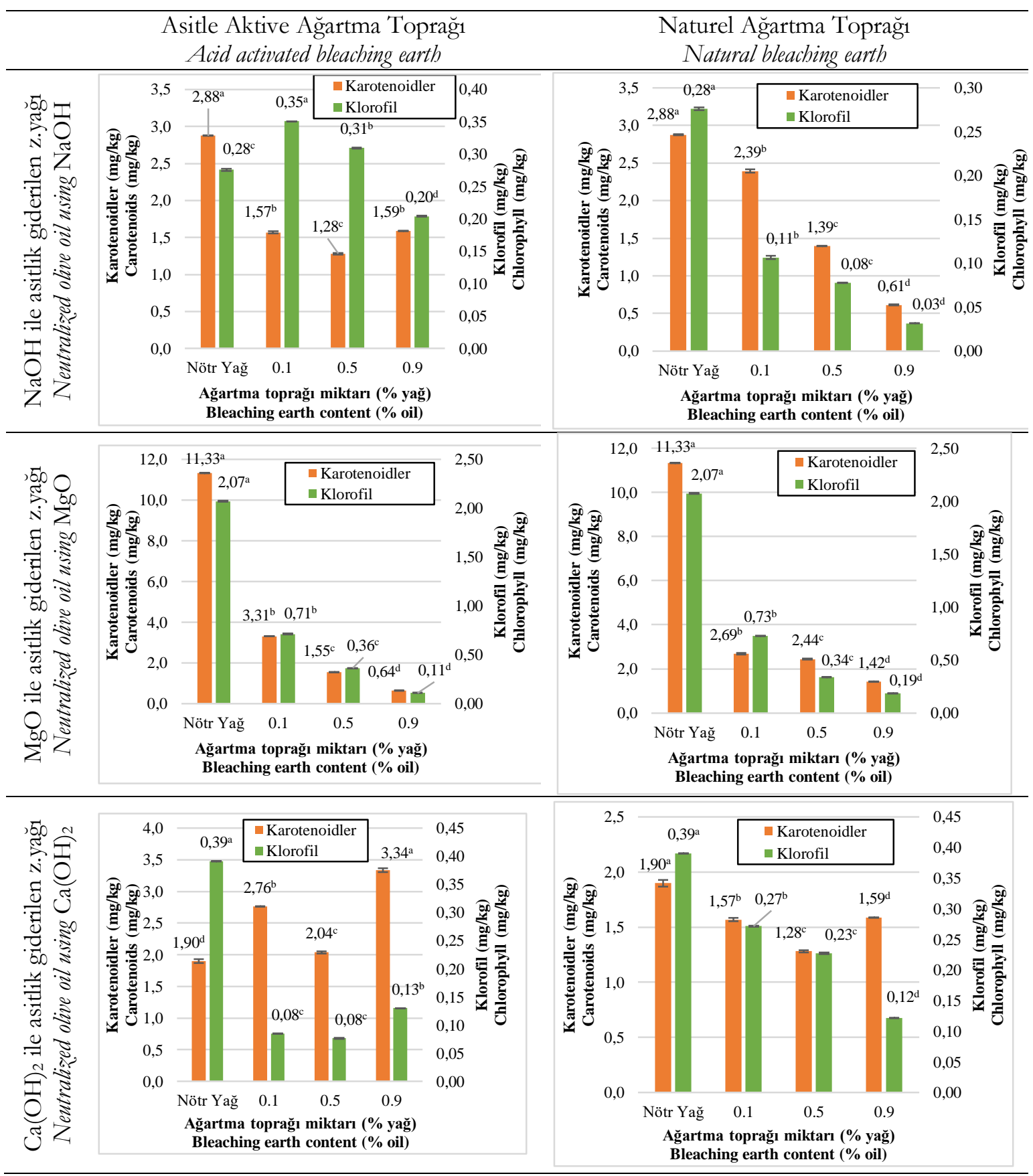

Her grafik için ayrı ayrı olacak şekilde kendi veri serisi içinde değişen üst indis harfler (karotenoid ve klorofil için ayrı ayrı değerlendirilmelidir), Tukey testine göre grup farklılıklarını ifade etmektedir. Karotenoid miktarı solda bulunan birincil eksende, klorofil miktarı ise sağda bulunan ikincil eksende gösterilmektedir.

Superscript letters (for carotenoid and chlorophyll must be evaluated separately), represent group differences according to Tukey test. The amount of carotenoid is shown on the primary axis on the left, and the amount of chlorophyll on the secondary axis on the right.

Şekil 4. $\mathrm{NaOH}, \mathrm{MgO}$ ve $\mathrm{Ca}(\mathrm{OH})_{2}$ ile asitlik giderme uygulanmış zeytinyağı örneklerinin değişken miktarlarda farklı ağartma topraklarıyla renk açma işlemine tabi tutulması sonucunda yağlardaki renk maddelerinin (toplam karoteniod ve klorofil miktarları) değişimi.

Figure 4. The change in the amount of coloring bodies (total carotenioid and chlorophyll amounts) as a result of the bleaching of olive oil samples treated with $\mathrm{NaOH}, \mathrm{MgO}$ and $\mathrm{Ca}(\mathrm{OH})_{2}$ at varying amounts of different bleaching soil. 


\section{SONUÇ}

$\mathrm{Bu}$ çalışmada, bitkisel yağlara uygulanan rafinasyon işlemleri sırasında gerçekleşen biyoaktif bileşen kayıplan üzerinde asitlik giderme işleminde kullanılan alkalinin kuvveti ve renk açma işleminde kullanılan ağartma toprağının tipi ve miktarının etkileri incelenmiştir. Yapılan çalışmada ayrıca uygulanan işlemlerin performans kriterleri de izlenerek çift yönlü yorumlama yapılmaya çalışılmıştır. Elde edilen sonuçlar öncelikle asitlik giderme işleminde $\mathrm{NaOH}$ ve $\mathrm{MgO}$ 'nun SYA miktarın $\% 7.58$ 'dan sirasiyla $\% 0.15$ ve $\% 0.29$ 'a düşürürken rafinasyon kayiplarının sirasiyla 0.27 ve 0.26 düzeyinde olduğu görülmüştür. $\mathrm{Ca}(\mathrm{OH})_{2}$ ile asitliği giderilen zeytinyağlarında rafinasyon kaybı değerleri 0.17 olarak daha düşük bulunmuş olsa da SYA ancak 3.25'e düşürülebilmiştir. $\mathrm{Ca}(\mathrm{OH})_{2}$ ile etkin bir nötralizasyon işleminin gerçekleşmemesi sonucunda özellikle $\alpha$-tokoferol değerinin diğer alkalilere göre daha yüksek seviyede $(318.12 \mathrm{mg} / \mathrm{kg}) \mathrm{kalmas}$ dikkat çekicidir. Asitliği giderilmiş örnekler arasında toplam fenolik madde miktarındaki en yüksek değer $175.3 \mathrm{mg} / \mathrm{kg}$ ile $\mathrm{NaOH}$ ile asitliği giderilmiş olan zeytinyağında tespit edilmiştir. Gerçekleştirilen asitlik giderme işlemleri rafinajlık zeytinyağının oksidasyon değerlerinde belirli bir azalmayı da sağlamıştır. Alkali tipleri arasinda $\mathrm{NaOH}$ ve $\mathrm{MgO}$ ile gerçekleştirilen asitlik giderme işlemlerinde 152.02 olarak tespit edilen başlangıç TOTOX değeri sırasıyla 47.82 ve 56.9 'a düşerken $\mathrm{Ca}(\mathrm{OH})_{2}$ ile gerçekleştirilen asitlik giderme işlemi sonrasında bu değer 123.53 'de kalmıştr. Asitlik giderme deneme sonuçları yorumlandığında, $\mathrm{NaOH}$ ve MgO'nun işlem etkinliği ve biyoaktif bileşen kaybını azaltma açısından genel anlamda $\mathrm{Ca}(\mathrm{OH})_{2}$ 'ye göre daha başarılı olduğu görülmüştür. Renk açma işlemleri genel olarak SYA ve TOTOX değerlerinde artışa neden olmuştur. Ancak asitlik giderme işlemi sonrasındaki SYA düzeyi düşük olan $\mathrm{NaOH}$ örneklerinde natürel ağartma toprağı kullanımının SYA değerlerinde önemli bir artışa neden olmadığ1 söylenebilmektedir. $\mathrm{Ca}(\mathrm{OH})_{2}$ ile asitliği giderilmiş olan zeytinyağlarının renk açma işlemleri sonrasinda oksidasyon değerlerinde önemli bir artış gözlenmemesi, başlangıç TOTOX değerinin yüksek olması ile açıklanabilmektedir.
$\mathrm{MgO}$ ile asitliği giderilmiş olan zeytinyağlarının renk açma işlemleri sonrasında ise ulaştı̆̆ TOTOX değerleri, $\mathrm{NaOH}$ örneklerinin yaklaşık iki katı olmuştur. Renk açma işleminin etkinliğini gösteren pigment miktarları incelendiğinde $\mathrm{Ca}(\mathrm{OH})_{2}$ ile asitliği giderilmiş örneklerde istenilen renk açma etkisinin her iki ağartma toprağı tipinde de gerçekleşmediği, bunun ise $\mathrm{Ca}(\mathrm{OH})_{2}$ 'nin yeterli miktarda asitlik ve oksidasyon ürünlerinde azalma sağlamaması ve muhtemel olarak bu maddelerin ağartma toprağının etkinliğini azaltması ile açıklanabilmektedir. $\mathrm{MgO}$ ile asitliği giderilmiş zeytinyağ ağartma toprağ1 kullanılması, hem etkin bir pigment maddesi adsorbsiyonu hem de toplam fenolik madde kaybında diğger alkalilere göre daha fazla azalma gerçekleşmesini sağlamıştır. $\alpha$ tokoferol kaybının en az yaşandığı renk açma denemesi ise $\mathrm{NaOH}$ ile asitliği giderilen zeytinyağ1 örneklerinin asitle aktive ağartma toprağ 1 ile renk açma işlemine tabi tutulması sonrasinda elde edildiği söylenebilmektedir. Yapılan çalışma asitlik giderme ve renk açma işlemlerinde alkali ve toprak tiplerinin bir optimizasyon süresi içerisinde değerlendirilmesiyle daha kesin sonuçların elde edilebileceği düşünülmektedir. Ayrıca bu maddelerin reaksiyon sirasinda yağ ile karışturılmasında ultrases gibi mekanik tekniklerden daha etkin yöntemlerin denenmesinin ileriki çalışmalarda araşturılması gerektiği kanısına varılmıştır.

\section{ÇIKAR ÇATIŞMASI BEYANI}

Yazarlar, bu makale ile ilgili başka kişi veya kurumlar ile çıkar çatışması olmadığını beyan eder.

\section{YAZAR KATKILARI}

Merve Yazllıkaya Parasiz: Denemelerin yapılması, sonuçların tablolaşturılması, metin yazımı. İlgili projede "bursiyer" olarak görev almıştr.

Onur Özdikicierler: İstatistiksel analizlerin gerçekleştirilmesi, literatürün derlenmesi, sonuçların yorumlanması, metin yazımı, iletişimdeki yazar olarak yayın sürecinde iletişimin yürütülmesidir. İlgili projede araştırmacı olarak görev almıştır ve "hak sahibi" konumundadır. 
Fahri Yemişçioğlu: Çalışmaların koordinasyonu. İlgili projede "yürütücü” olarak görev almıştr.

\section{TEŞEKKÜR}

$\mathrm{Bu}$ çalışmaya $118 \mathrm{O} 183$ numaralı proje kapsamında destek sağlayan TÜBİTAK'a teşekkürlerimizi sunarız.

\section{KAYNAKLAR}

Boskou, D. (2009). Olive Oil: Minor Constituents and Health. (D. Boskou, Ed.). Boca Raton: CRC Press.

Brien, R. D. O., Farr, W. E., Wan, P. J. (2000). Introduction to Fats and Oils Technology. (R. D. O. Brien, W. E. Farr ve P. J. Wan, Ed.). Champaign, Illinois: AOCS Press.

Cmolik, J., Pokorny, J. (2000). Physical refining of edible oils. Eur. J. Lipid Sci. Technol., 102:472-486.

De, B. K., Patel, J. D. (2011). Refining of rice bran oil by neutralization with calcium hydroxide. Eur. J. Lipid Sci. Technol., 113(9):1161-1167. doi:10.1002/ejlt.201000343

Ghazani, S. M. (2012). The Influence of Traditional and Minimal Refining on the Minor Constituents of Canola Oil. The University of Guelph.

Ghazani, S. M., García-Llatas, G., Marangoni, A. G. (2013). Minor constituents in canola oil processed by traditional and minimal refining methods. J. Am. Oil Chem. Soc., 90:743-756. doi:10.1007/s11746-013-2215-2

Ghazani, S. M., Marangoni, A. G. (2013). Minor components in canola oil and effects of refining on these constituents: A review. JAOCS, J. Am. Oil Chem. Soc., 90:923-932. doi:10.1007/s11746013-2254-8

Gıda Tarım ve Hayvancılık Bakanllğı. (2017). Zeytinyağ1 ve Pirina Yağ1 Tebliği. Türk Gıda Kodeksi. http://www.resmigazete.gov.tr/eskiler/2017/09 /20170917-9-1.pdf adresinden erişildi.

Lucci, P., Bertoz, V., Pacetti, D., Moret, S., Conte, L. (2020). Effect of the refining process on total hydroxytyrosol, tyrosol, and tocopherol contents of olive oil. Foods, 9(3):1-11. doi:10.3390/foods 9030292

Pan, F., Wen, B., Wang, X., Ma, X., Zhao, J., Liu, C., ... Dang, W. (2019). Effect of the chemical refining process on perilla seed oil composition and oxidative stability. J. Food Process. Preserv., (November 2018):1-10. doi:10.1111/jfpp.14094

Preedy, V., Watson, R. (2010). Olives and Olive oil in Health and Disease Prevention. (V. R. Preedy ve R. R. Watson, Ed.). London, UK: Elsevier Academic Press.

Sabah, E., Çelik, M. S. (2005). Sepiolite: An effective bleaching adsorbent for the physical refining of degummed rapeseed oil. J. Am. Oil Chem. Soc., 82:911-916. doi:10.1007/s11746-0051164-4

Shahidi, F. (2005). Bailey's Industrial Oil and Fat Products. (F. Shahidi, Ed.) (6. Edition.). New York: John Wiley \& Sons, Inc.

Sönmez, A., Özdikicierler, O., Gümüşkesen, A. S. (2018). Evaluation of olive oil quality during the ripening of the organic cultivated olives and multivariate discrimination of the variety with a chemometric approach. La Riv. Ital. Delle Sostanze Grasse, XCV:173-181.

Verhé, R., Verleyen, T., Van Hoed, V., De Greyt, W. (2008). Influence of refining of vegetable oils on minor components. Proc. - $2008 \mathrm{Jt}$. Cent. Eur. Congr. 4th Cent. Eur. Congr. Food, CEFood 2008 6th Croat. Congr. Food Technol. Biotechnol. Nutr., 1:5569. 